\title{
Baret Kazıklı Radye Temellerin Üç Boyutlu Sonlu Elemanlar Analizi
}

\author{
Halil Murat ALGIN ${ }^{1}$ \\ Arda Burak EKMEN ${ }^{2}$ \\ Levent YENMEZ ${ }^{3}$
}

ÖZ

Yüksek katlı yapı temellerinde kullanılan baret kazıklı radye sistemlerinin oturma analizlerinin yapılması, geoteknik mühendisliği açısından yeni bir bilimsel mücadele alanı olmuştur. Bu temel sistemlerinin sayısal üç boyutlu modellerinin görüntü işleme tekniğiyle daha gerçekçi olarak yapılabildiğini göstermek amacıyla, Viyana'daki Avrupa'nın en uzun gökdelenlerinden biri olan Donau-City (DC) kulelerinin temel sistemleri ayrıntılı bir şekilde modellenmiş ve kulelerin birbirlerine etkisi incelenmiştir. $\mathrm{Bu}$ araştırma kapsamında geliştirilen üç boyutlu sonlu elemanlar (3B SE) modelleri sayesinde, geoteknik mühendisliğinde önemli bir temel çeşidi olan baret kazıklı radyelerin oturma analizleri, komşu kazık sistemiyle birlikte analiz edilerek ölçüm sonuçlarıyla kıyaslanmıştır. Bu çalışmada sunulan analizler sayesinde, literatürde daha önce tanıtılan 3B SE analizlerinin geliştirilerek oturma analizlerinin daha hassas bir şekilde ileri bir modelleme tekniği ile yapılabileceği açıklanmıştır.

Anahtar Kelimeler: Baret kazıklı radye, görüntü işleme, sonlu elemanlar analizi, üç boyutlu modelleme, oturma analizi.

\section{ABSTRACT \\ 3D Finite Elements Analysis of Barrette Piled Raft Foundations}

The settlement analysis of barrette piled raft systems used for high-rise building foundations has become a new challenging research area for the geotechnical engineering design. The foundation systems of the Donau-City (DC) towers in Vienna that are one of the longest skyscrapers in Europe have been modelled in detail to demonstrate that the three-dimensional

Not: Bu yazı

- Yayın Kurulu’na 28 Şubat 2018 günü ulaşmıştır. 29 Ağustos 2018 günü yayımlanmak üzere kabul edilmiştir.

- 30 Kasım 2019 gününe kadar tartışmaya açıktır.

- https://dx.doi.org/10.18400/tekderg.399679

1 Harran Üniversitesi, İnşaat Mühendisliği Bölümü, Şanlıurfa - hmalgin@harran.edu.tr https://orcid.org/0000-0001-7848-5464

2 Harran Üniversitesi, İnşaat Mühendisliği Bölümü, Şanlıurfa - ardaburakekmen@harran.edu.tr https://orcid.org/0000-0002-9703-2185

3 Harran Üniversitesi, İnşaat Mühendisliği Bölümü, Şanlıurfa - leventyenmez@harran.edu.tr https://orcid.org/0000-0002-6283-8269 
models of this foundation system can be conducted realistically using the novel image processing techniques. The 3D finite element (3D FE) models developed within the scope of this research have been analysed together with the neighbouring piled raft system and the results are compared with the actual measured values. The presented paper provides to take this advanced modelling one step forward by introducing a novel technique to these complex foundation systems.

Keywords: Barrette piled raft, image processing, finite elements analysis, 3D modelling, settlement analysis.

\section{GİRiș}

Baret kazıklar genelde dikdörtgen kesitli inşa edilmekte olup yüksek düzeyde yük taşıma kapasitesine sahiptir ve kısa grup kazıklar tarafından taşınması pratik olmayan temel yapılarını, ekonomik ve güvenli olarak taşımayı hedefler. Büyük kesitli dikdörtgen kazık formundaki baretler derin temel sistemlerinde [1-4] ve yol inşaatlarında [5] kullanılmaktadır. Baret kazık kesitinin dikdörtgen formu, daha iyi bir sürtünme direnci oluşması açısından önemli olup uzunluk ve genişliği sırasıyla $1.2-7 \mathrm{~m}$ ve $0.6-1.5 \mathrm{~m}$ arasında değişmektedir. Baretlerin yük taşıma kapasitelerinin delgi kazıkları kadar verimli olduğu Kienberger [6] tarafından belirtilmiştir.

Bentonit çamuru, çelik donatı sepeti ve tremi betonlamadan oluşan genel diyafram duvar inşa uygulamalarına oldukça benzer bir metotla inşa edilen baret kazıklar, özellikle yer altı su seviyesinin yüksek ve taşıyıcı sağlam tabakanın oldukça derinde olduğu, ince daneli zemin ihtiva eden birimlerin oluşturduğu temel zeminlerinde yapılan bir derin temel uygulamasıdır. $\mathrm{Bu}$ bağlamda, baret kazıklar büyük çaplı delgi ve yerinde döküm kazıklarına alternatif oluşturmaktadır. Buna ek olarak inşa sürecinde çevrede oluşan gürültü vb. olumsuz etkilerin daha az olduğu ifade edilmiştir [2]. Düşey yük taşıma kapasitesinin yanında yapısal tasarımda belirtilen belli değerde yatay yük ve eğilme moment değerinin de baret kazıklar tarafından taşınması beklendiğinden, bazen birleşik dikdörtgen kesitli olarak da inşa edilirler. Atalet ve eğilme moment direncini arttırmak amacıyla temel tasarımında baret kazıkların yönleri ve uyumlanmaları değişmekte olduğundan, dairesel kesitli kazıklardan farklı olarak, baret kazıkların bu yön etkilerinin de optimum tasarım açısından değerlendirilmesi gerekmektedir.

Derin kazı gerektiren projelerde diyafram duvar uygulaması yanında, aynı inşa makinesi kullanıldığından genelde baret kazık imalatı da yapılmaktadır. Böylelikle, diğer türden makinelerin saha içerisinde kullanılma zorluğu aşılarak, ekonomik ve hızlı imalat mümkün olabilmektedir. Son kırk yıldır baret kazıklar dünya genelinde yaygın bir şekilde kullanılmakta olup, dünyanın en uzun gökdelenlerinden biri olan, Malezya, Kuala Lumpur'daki Petronas ikiz kulelerinin 40-105 m derinlikli baret sürtünme kazıklı temeli [7] ve bu yayında analiz edilen Viyana'daki Avrupa'nın en uzun gökdelenlerinden biri olan Donau City (DC) kulelerinin derin temel sistemleri [8] bu kazık uygulamasına örnek olarak verilebilir. Baret kazıklar derin kazı duvarları, ağır yapılar vb. için verimli ve oldukça güvenilir bir metot olmasından ötürü, yüksek katlı bina temellerinde yaygın bir kullanım alanı bulmaktadır. Bu temel sistemlerinin oturma analizlerinin daha hassas bir şekilde yapılabilmesi açısından, söz konusu temel sistemini etkileyen temel parametrelerdeki değişimlerin yanında, komşu temellerin etkisini de dikkate alacak şekilde bir bütünsel analiz ihtiyacına bu yayında cevap verilmektedir. 
Derin baret kazıkların dünya genelinde kullanımına karşın, bu kazıkların tasarım analizlerinde hala ampirik yaklaşımlar kullanılmakta olup, baretlerin sağlam zemin tabakasına oturtulması veya aşırı yüksek düzeyde güvenlikli inşa edilmesi ile ilgili tasarım rehberleri mevcuttur [9]. Genel olarak müsaade edilen birim yüzey direnci ve uç taşıma basıncı için düzeltilmemiş SPT N değerlerinden yararlanılmaktadır [10]. Bu yaklaşımların bazı durumlarda, özellikle sağlam zemin tabakasının derinde olduğu bölgelerde, baret kazıkların aşırı tasarımla boyutlandırılmalarına yol açtığı $\mathrm{Ng}$ ve Lei [9] tarafından ifade edilmektedir. Baretlerin kazık-zemin arayüzünde oluşan yüzey direnci dikkate alınarak tasarlanmasının önemli bir ekonomik fayda sağladığı raporlanmıştır [9].

Baret kazıkların nümerik analiziyle ilgili mevcut literatürde sınırlı sayıda araştırma bulunmaktadır. Baret kazık uygulamasına benzeyen diyafram duvar panelleri, Powrie ve Li [11] tarafından iki boyutlu sonlu elemanlar metoduyla analiz edilmiştir. Daha sonra Gunn ve diğ. [12], Moran ve Laimbeer [13] düzlem deformasyon kabulüyle diyafram duvar panellerin inşa aşamalarını analiz etmişlerdir. Diyafram duvar panellerin inşa edilmesi sürecinde taze betonun hidrostatik etkisini gözeterek $\mathrm{Ng}$ [14] ve Lings vd. [15], düzlem gerilme kabulünü yatay düzlemde, düzlem birim deformasyon kabulünü düşey düzlemde dikkate alarak sonlu eleman analizleri yapmıştır. Böylelikle inşa aşamalarında diyafram duvar panellerinde oluşan yatay kemerlenme ve yük iletme mekanizmaları ile, inşa sürecinde zemine iletilen gerilme durumları açıklanmaya çalışılmıştır. $\mathrm{Ng}$ ve Yan $[16,17]$ tarafından sonlu farklar metodu temelinde üç boyutlu nümerik analizle tek bir diyafram duvar panelinin davranış mekanizması incelenmiş ve $\mathrm{Ng}$ ve diğ. [18] tarafından önerilen gerilme transfer mekanizması bu yolla araştırılmıştır. Gourvenec ve Powrie [19] sonlu eleman analizleriyle diyafram duvar panellerinin üç boyutlu etkilerini ve panel uzunluğunun yatay zemin yüzeyindeki deformasyona etkisini araştırmışlardır. İnşaat esnasında bir diyafram duvarın yakınındaki yanal gerilme azalmasının büyüklüğü ve boyutunun, panel uzunluğuna bağlı olduğunu ve düzlem birim deformasyon koşullarını varsayan analizlerde aşırı olarak tahmin edildiğini belirtmişlerdir. Üç boyutlu etkiler, düzlem birim deformasyon durumuna kıyasla, inşa sürecinde panel formundaki diyafram duvarın yanal deplasmanını azaltma eğilimindedir.

Fellenius ve diğ., [20] tarafından yapılan sonlu elemanlar (SE) analizinde, özel bir yazılım kullanılmış olup, analiz düzlem birim deformasyon durumunda gerçekleştirilmiş ve zemin elastoplastik malzeme kabulüyle modellenmiştir. Kazık gruplarının grup etkisinin yanında komşu temel sisteminin etkisi de bu SE modellemesine dahil edilmemiştir [20]. Lei [21] tarafından sonlu farklar metodu temelinde simetriden yararlanılarak bir baret kazığın çeyrek kısmı üç boyutlu olarak modellenmiştir. Baret kazıklar üzerinde bir diğer nümerik analiz Zhang [22] tarafından üç boyutlu olarak sonlu elemanlar metodu temelinde yapılmış olup, sadece tek bir baret kazığın analizi gerçekleştirilmiş ve yükleme test sonuçlarıyla karşılaştırılmıştır. Seo ve diğ. [23] tarafından baret kazıkların oturma analizlerinin analitik olarak yapılabilmesi amacıyla, bir metodoloji önerilmiş ve nümerik analizle doğrulaması yapılmıştır. Ancak, bu nümerik analizde de sadece tek bir kazık modellenmiştir. Ann ve Fellenius [4] tarafından yayınlanan çalışmada ise test edilen baret kazığının sonlu elemanlar simülasyonu yapılmış ve eksenel simetrik modellemeyle üç boyutlu davranış tek bir kazık için incelenmiştir. Bu analizlerde eksenel simetrik model kullanılması baretin dikdörtgen kesitli geometrisi sebebiyle tartışılabilecek bir durum oluşturmuştur.

Yukarıda bahsedilen bu araştırmalar, analiz türü, zemin profili, baret veya panel modeli ve boyutları, zemin modeli ve drenaj koşullarına göre farklılıklar göstermektedir. Tüm bu 
analizler genel olarak zemin koşulları ve baret kazık geometrileri bakımından farklı olup, genel bir sonuç çıkarmak zordur, ancak bu çalışmaların hiçbiri bu yayında sunulan modelleme gibi komşu temellerin etkisini de içerecek şekilde bir deformasyon analizi sunmamıştır. Tanıtılan bu yayının amacı baret kazık uygulaması içeren karmaşık bir temele sahip olan Viyana'daki DC kulelerinin derin temel sistemleri ve karşılıklı etkileşimlerini üç boyutlu olarak sonlu eleman metoduyla analiz etmektir. Temel sistemi, önceki çalışmalarda ([8], [24-27]) ifade edilen proje detayları dikkate alınarak, Algin [28, 29] tarafindan tanitılan görüntü işleme tekniği kullanılarak modellenmiş ve üç boyutlu sonlu elemanlar (3B SE) modellerinin oturma analizleri gerçekleştirilmiştir. Elde edilen analiz sonuçları, önceki çalışmalar ve arazi ölçüm sonuçları ile kıyaslanmıştır.

\section{DC KULELERININ TEMEL SISTEMI VE ZEMIN KOȘULLARI}

Yakın zamanda inşa edilen Viyana'daki DC kulelerinden birincisi Avrupa'nın en yüksek gökdelenlerinden biri olup $220 \mathrm{~m}$ yüksekliğindedir. İkinci kulenin yüksekliği ise $168 \mathrm{~m}$ olarak belirlenmiştir. Kuleler birbirine çok yakın konumlandırılmış olduklarından, bu iki kulenin etkileşimi bu yayın kapsamında incelenmiştir (Şekil 1). İki kule arasındaki mesafe, Şekil 2'deki temel planından da görülebileceği üzere, $24 \mathrm{~m}$ olarak projelendirilmiştir. İki kulenin temel sistemlerindeki radyenin inşası için yapılan kazı derinliği $6.6 \mathrm{~m}$ civarındadır (Şekil 3). Bu yapılarda kullanılan temel radye ve kazık sistemleri Şekil 2'de sunulmuştur. Şekil 2'den görüleceği üzere derin temel sistemi pek çok baret ve Continuous Flight Auger (CFA) kazık uygulaması içermektedir. Sonlu elemanlar modellemesinde temel alınan zemin profili [8], Şekil 3'te sunulmuştur. Her ne kadar, bu zemin profilinde sondaj kuyuları arasında farklılıklar görülmüş olsa da temel anlamıyla tabakalı bir zemin tanımına uygun ortak profil Şekil 3 'te gösterildiği gibi tanımlanabilir. İlgili arazide yer altı suyu seviyesi 2.6 metredir. Analiz aşamasında efektif parametrelerin kullanımı ile bu durum modele yansıtılmıştır.

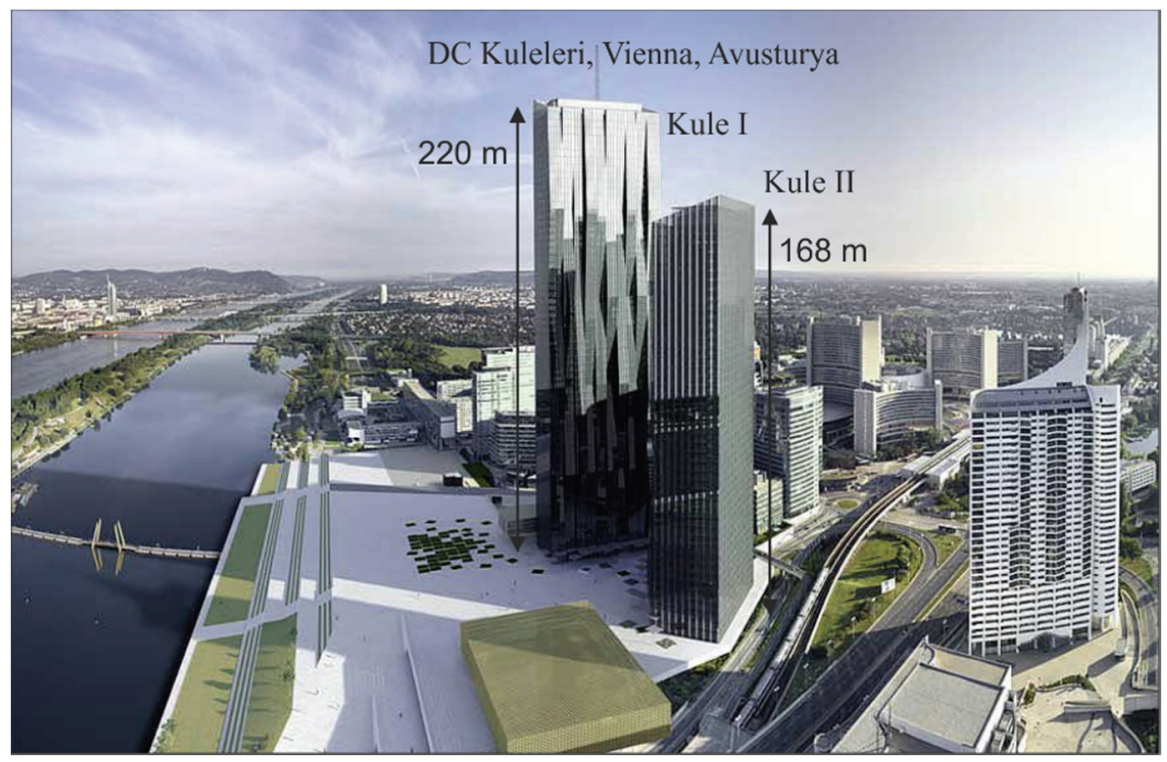

Şekil 1 - Donau City (DC) Kuleleri, Viyana 


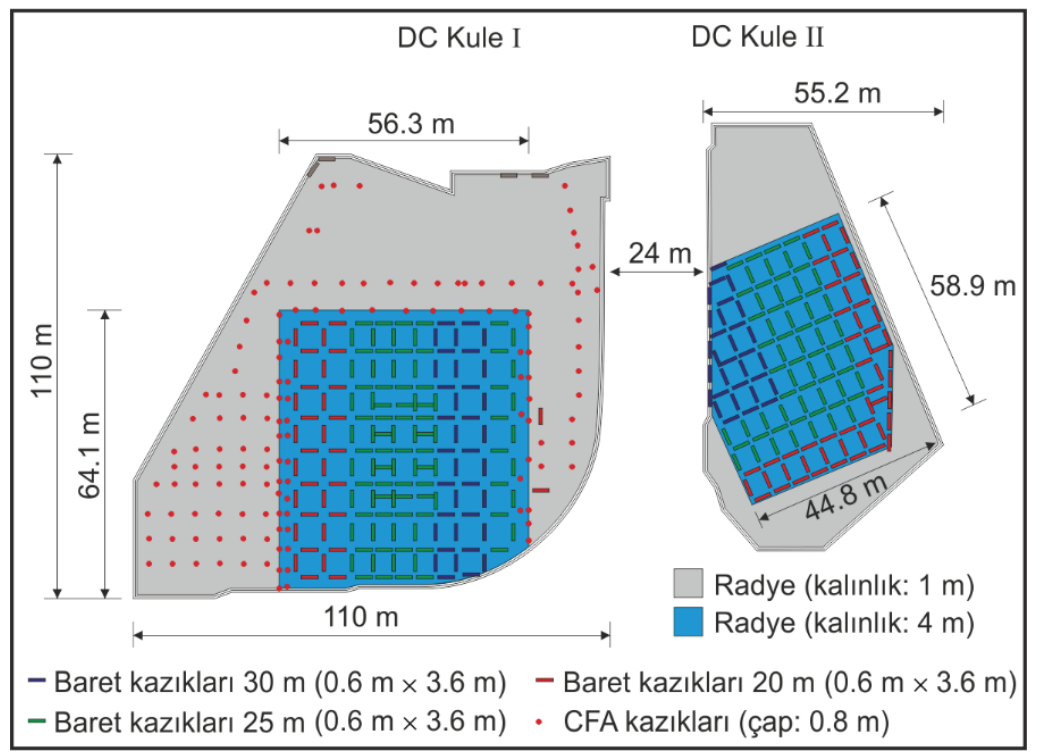

Şekil 2 - Kulelerin konumları, yeraltı otoparkı ve kazık temellerin yerleşimleri

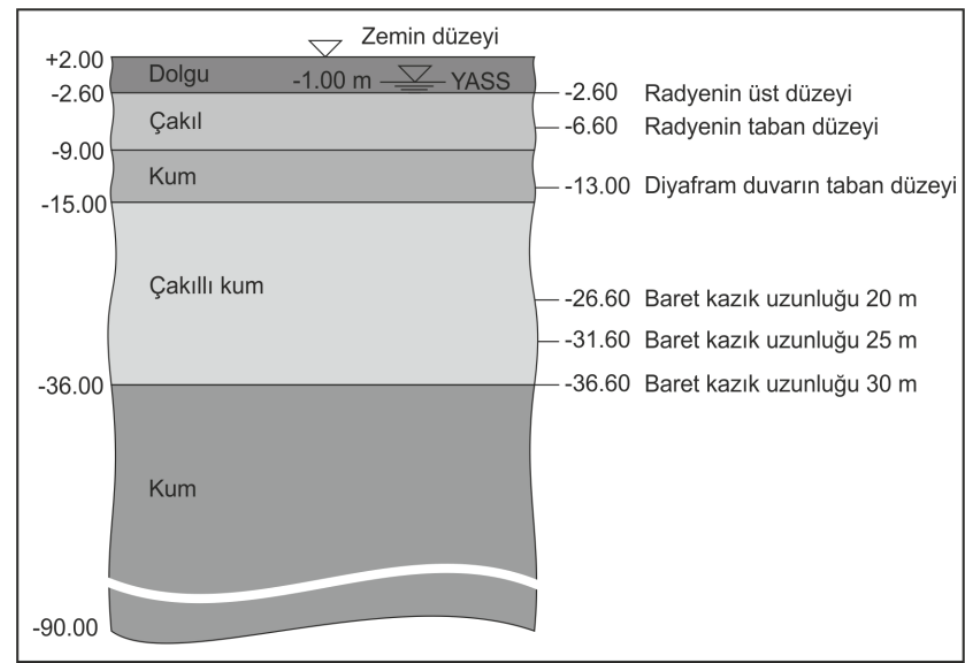

Şekil 3 - 3B SE Modellemesi yapılan zemin profili

Bu çalışmada modellenen DC kulelerinin baret ve CFA kazıklı derin temel sistemleri Adam ve Markiewicz [24], Tschuchnigg ve Schweiger'in [25] çalışmalarındaki geometrik veriler esas alınarak modellenmiştir. Şekil 2'de görülebileceği üzere, temel sisteminde $20 \mathrm{~m}, 25 \mathrm{~m}$ ve $30 \mathrm{~m}$ olmak üzere farklı uzunlukta baretler inşa edilmiştir. CFA kazıkları $20 \mathrm{~m}$ uzunluğunda uygulanmıştır. CFA ve Baret kazıkları betonarme olarak diyafram duvar ile 
yerinde imal edilmiştir. Diyafram duvar kalınlığ $10.6 \mathrm{~m}$ olup kazıklar $0.8 \mathrm{~m}$ çapındadır. Çizelge 1'de çalışmada kullanılan malzemelerin özellikleri gösterilmiştir. Şekil 2 ve 3'te kazıklı derin temel sistemi ve kazıkların yerleşimi görülmektedir. Şekil 2'de görülebileceği üzere, birinci kulenin baret kazıklarının yerleşiminin ve boylarının tasarlanmasında, birinci kule için üniform bir oturma davranışı elde etmek ve ikinci kulenin, birinci kule üzerinde oluşturacağı etkileri azaltmak amacıyla baret kazık boyu olarak 20 m, 25 m, 30 m ve 25 m sıralaması kullanılmıştır [26, 27].

Çizelge 1 - Malzemelerin özellikleri

\begin{tabular}{lccccc}
\hline \multicolumn{1}{c}{ Malzeme } & $\gamma_{n}\left(\mathrm{kN} / \mathrm{m}^{3}\right)$ & $E(\mathrm{MPa})$ & $v$ & $c^{\prime}(\mathrm{MPa})$ & $\phi^{\prime}\left({ }^{\circ}\right)$ \\
\hline Kum (MC) & 19.5 & 216 & 0.2 & 0.022 & 32 \\
\hline Çakıl (MC) & 21 & 320 & 0.2 & 0 & 33 \\
\hline Çakıllı Kum (MC) & 19 & 300 & 0.2 & 0.015 & 30 \\
\hline Dolgu (MC) & 21 & 120 & 0.2 & 0 & 33 \\
\hline Diyafram Duvar (LE) & 25 & 33000 & 0.2 & - & - \\
\hline İnce Radye Temel (LE) & 25 & 33000 & 0.2 & - & - \\
\hline Kalın Radye Temel (LE) & 25 & 33000 & 0.2 & - & - \\
\hline CFA Kazıkları (LE) & 25 & 33000 & 0.2 & - & - \\
\hline Baret Kazıklar (LE) & 25 & 33000 & 0.2 & - & - \\
\hline
\end{tabular}

\section{3. ÜÇ BOYUTLU SONLU ELEMANLAR ANALİZi}

Algin [28-30] tarafından açıklanan görüntü işleme tekniği kullanılarak gerçekleştirilen 3B $\mathrm{SE}$ ağ modeli Şekil 4'te sunulmuştur. Bu model ağ yaklaşık 1.5 milyondan fazla dört üçgen yüzlü hacimsel element ihtiva etmekte olup, kazık grupları ve radye temel etrafinda element sıklaştırılması yapılarak global element sayısı azaltılmaya çalışılmıştır. Oturma analizleri açısından model sınırları Şekil 4'te gösterildiği gibi tasarlanmıştır. Modelin derinliği $90 \mathrm{~m}$ olup, kazık boylarının uzun olmasından dolayı bu model derinliği kullanılmıştır. Model oluşturulurken inşa aşamalarının etkisi dikkate alınmamış olup, son aşama yerinde arzulanan tarzda modellenmiştir. Ancak, başlangıç gerilmeleri dikkate alınarak analizler yapılmıştır. Önce diyafram duvar ve kazı modellenmiş ancak kazı içine akış, modele dahil edilmemiş ve sızma analizi yapılmamıştır. Baret ve CFA kazıklar aynı aşamada modellenmiş olup, zamana bağlı deformasyon analizi yapılmamıştır. Ancak efektif parametreler kullanılarak efektif analiz yapılmış ve yükleme aşamalı olarak uygulanarak inşa aşamaları incelenmiştir. Modelde, kazık yüzeyleri ve zemin arasındaki etkileşimi tanımlamak için Coulomb sürtünme katsayısı 0.7 olarak alınmıştır. Şekil 2‘de gösterilen DC Kule I’in kalın radye temeli için son aşamada nihai $710 \mathrm{kPa}$ ve çevreleyen diğer bölge için $50 \mathrm{kPa}$; DC Kule II’nin kalın radyesi için $540 \mathrm{kPa}$ ve çevre radye temel için $50 \mathrm{kPa}$ olarak temel yükleri üniform basınç şeklinde uygulanmıştır. Yüklerin belirlenmesinde binanın kendi ağırlığı ve bina üzerine gelecek hareketli yükler dikkate alınmıştır. Model boyutları Şekil 4'te görülebileceği üzere $361 \mathrm{~m} \times$ $321 \mathrm{~m} \times 90 \mathrm{~m}$ olup, zeminin malzeme özellikleri Şekil 3'te sunulan tabaka sistemine bağlı olarak derinlikle değiştirilmiştir. Şekil 5'te geliştirilen model ağın alttan yakın olarak 
görünümü sunulmuş olup temel sistemlerindeki $20 \mathrm{~m}, 25 \mathrm{~m}$ ve $30 \mathrm{~m}$ olmak üzere farklı boylardaki baret kazıklar, diyafram duvar sistemleri, CFA kazıklar ve radyeler ağ olarak yakından görülmektedir. Yük tanımlama işleminin ardından modele sınır koşulu tanımlanmıştır. Modelin tabanı ve yan yüzeyleri her yönden mesnetlenmiş ve hareketi Şekil 6 'da gösterildiği gibi sınırlandırılmıştır.

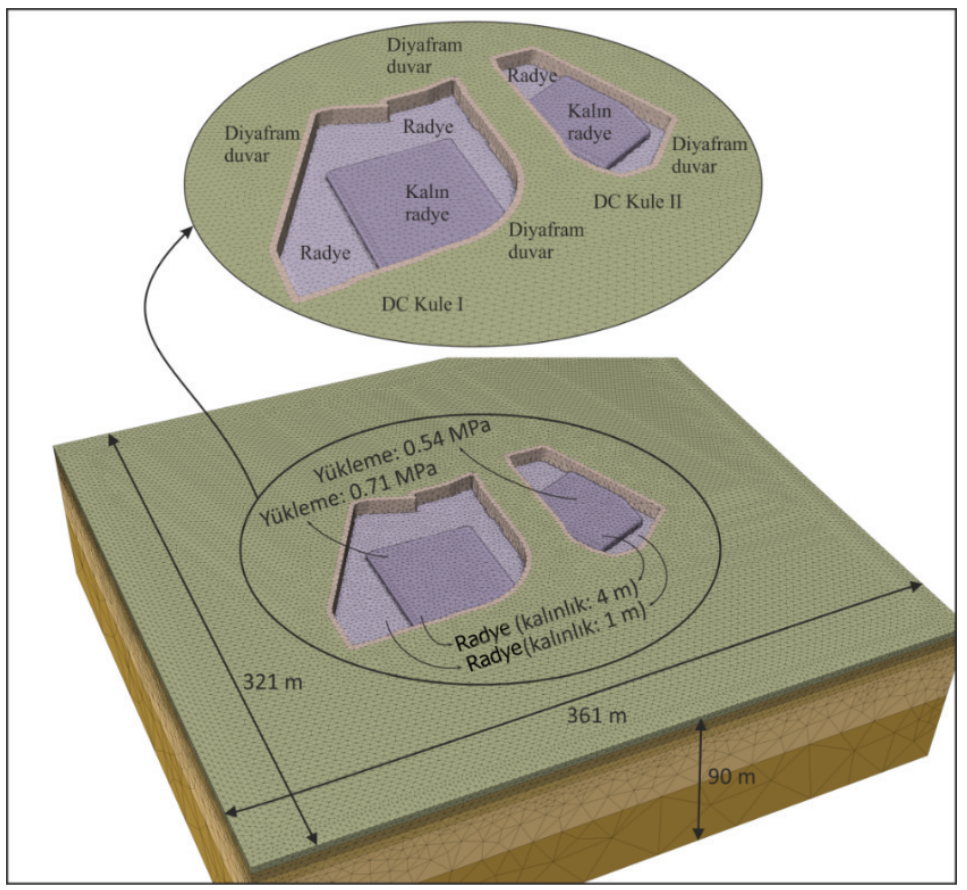

Şekil 4 - Modellenen zemin ve temel sistemlerinin genel görüntüsü

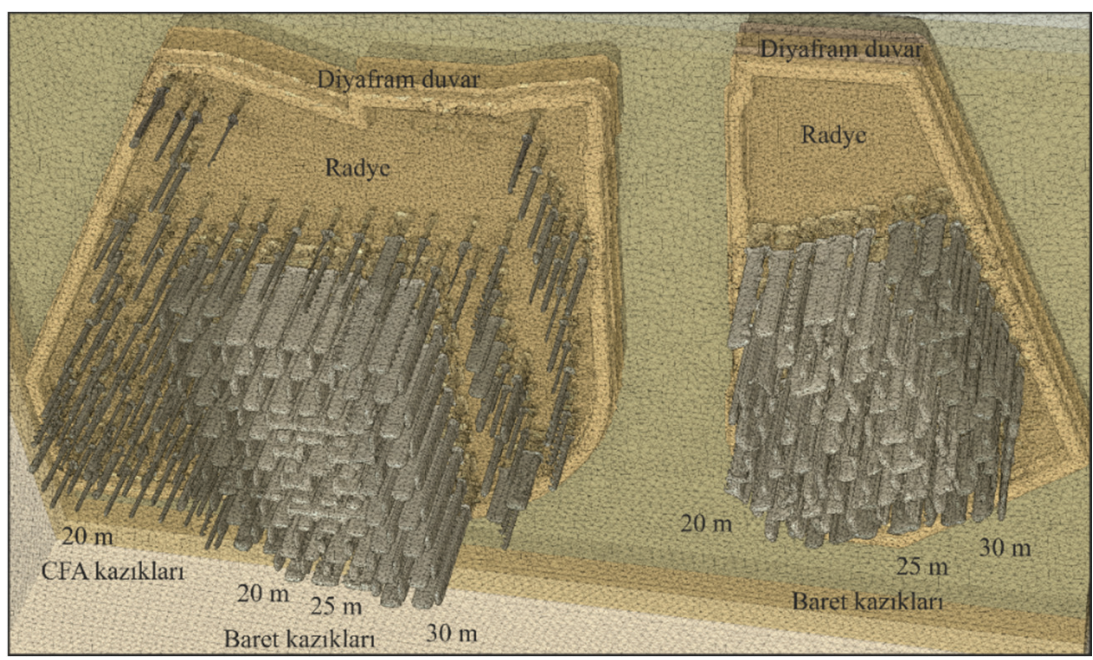

Şekil 5 - Kazık sisteminin alttan görünüşü 


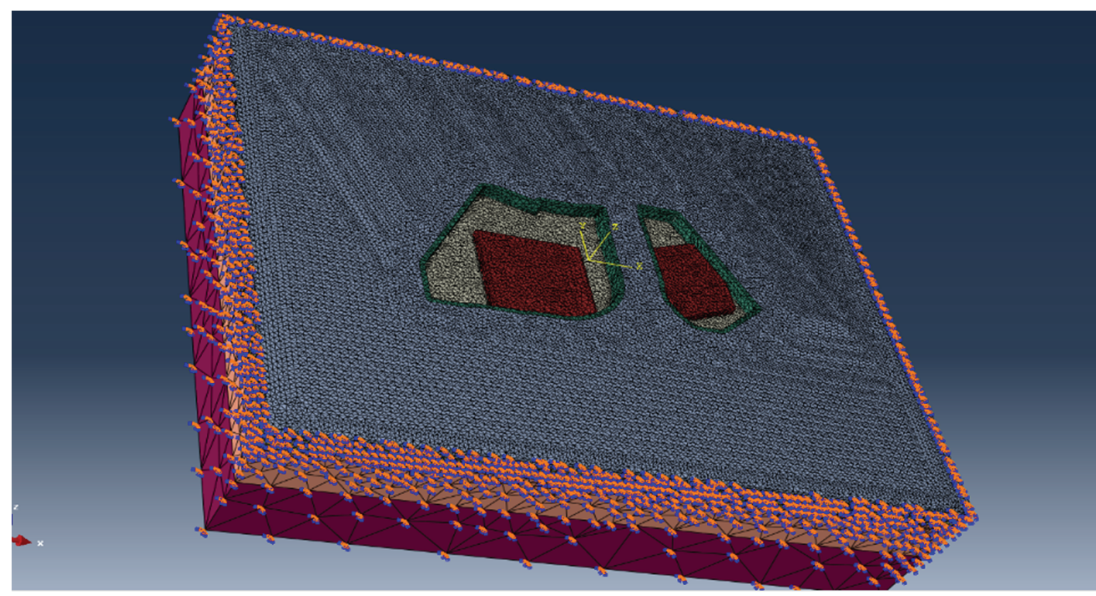

Şekil 6 - Geliştirilen modelin sınır koşul uygulaması

\section{GÖRÜNTÜ İŞEME TEKNİĞINIIN KULLANIMI}

Geoteknik tasarımlarda sayısal modellerin hacimsel görüntü verileri kullanarak oluşturulması, literatürde ilk defa bu makalenin yazarlarından Algin [28-30] tarafından tanıtılmış olup, bu metot sayesinde karmaşık geoteknik modellerin yapı-zemin etkileşimlerinin ayrıntılı olarak modellenebilmesi sağlanmıştır. Bu makalede tanıtılan baret kazıklı radye temel sisteminin modellemesi de bu teknik kullanılarak gerçekleştirilmiştir. Şekil 7 bu modelleme tekniğinin aşamalarını özetlemekte olup görüldüğü gibi gri ölçek değerlerine sahip pikseller kullanılarak görüntüler model derinliği boyunca hassas olarak tüm malzeme ve geometrik farklılaşma aşamalarını kapsayacak şekilde oluşturulmaktadır. Derinlik boyunca değişen kesitleri gösteren bu görüntüler, daha sonra piksel verilerine göre malzemelerin hacimsel geometrilerini oluşturacak şekilde bir araya getirilmekte ve bu aşamada tüm oluşturulan çoklu görüntüler kullanılmaktadır. Bu görüntü işleme aşamalarında, geoteknik analizler için özel olarak düzenlenmiş olan Python dilindeki görüntü işleme açık

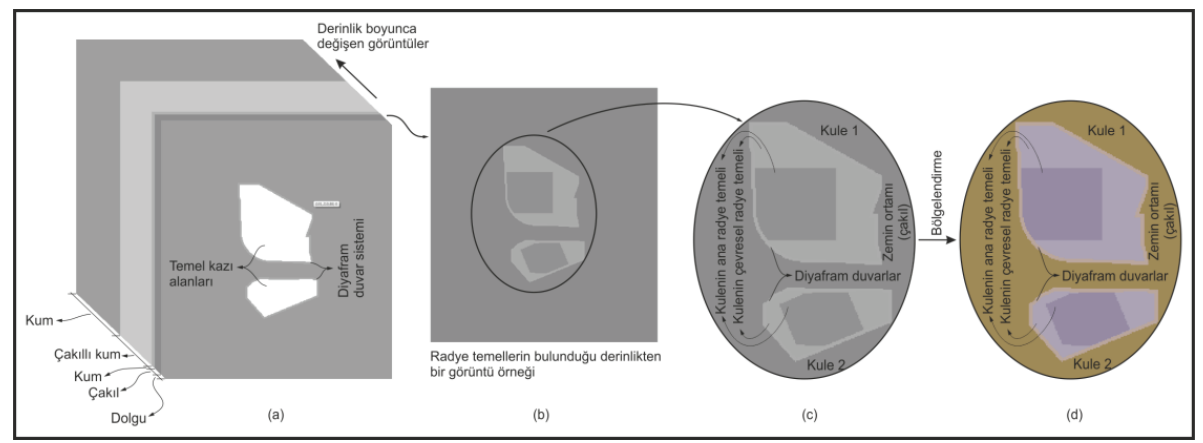

Şekil 7 - Görüntü işleme tekniğinin modelleme aşamasıda kullanımı, (a) derinlik boyunca değişen görüntüler, (b) oluşturulan tipik bir görüntü örneği, (c) görüntüdeki gri ölçekli renk tonlarının anlamları, (d)gri ölçek bilgilerine göre bölgelendirme işlemi 
kaynak kodlamalarından ve Matlab [31] yazılımlarından yararlanılmaktadır. Oluşturulan hacimsel görüntü verileri Matlab [31] ortamında morfolojik aşama denilen işlemden geçirilerek, bölgelendirmenin daha iyi oluşturulabilmesi sağlanmaktadır. Bu kapsamda görüntüler, spesifik olarak oluşturulduğundan önceden filtreleme işlemine çoğunlukla ihtiyaç duyulmamaktadır, ancak bu durum arzulanan model hassasiyetine bağlı olarak değişebilmektedir. Oluşturulan hacimsel geometri daha sonra Abaqus [32] yazılımına transfer edilmekte ve sonlu elemanlar analizleri bu yazılım kullanılarak yapılmaktadır.

\section{ANALIZZ SONUÇLARI VE TARTIŞMA}

Yapılan analiz sonuçları ile ilgili bir örnek görüntü Şekil 8'de sunulmuştur. Abaqus [32] programı kullanılarak tamamlanan analizler sonucunda elde edilen oturma değerleri incelendiğinde yüklerin radye temeller üzerine üniform olarak uygulanmasına rağmen baret ve CFA kazıklarının yerleşimleri ve uzunluklarındaki değişimlerde kullanılan yöntem sebebi ile maksimum oturmaların merkezin dışına doğru kaydığg görülmektedir. Kulelerin birbirine bakan cephelerinin altına yerleştirilen baret boylarının uzun ve diğer cephelerinin altına yerleştirilen baret boylarının nispeten kısa tutulmasının temel amacı, kulelerin birbirleri üzerindeki etkileri azaltmak, kuleler arasındaki bölgede yüksek diferansiyel oturmaların oluşmasını engellemek ve üniform oturmalar elde etmek şeklinde ifade edilmiştir [26, 27]. Analizler sonucunda elde edilen oturma değerlerine bakıldığında kulelerin arasındaki bölgede daha düşük oturma değerleri elde edildiği ve tasarım aşamasında amaçlanan hedefe kısmen ulaşıldığ1 görülmektedir. Analizler sonucunda birinci kulenin altında $49.57 \mathrm{~mm}$ maksimum oturma değeri elde edilmiştir (Şekil 8).

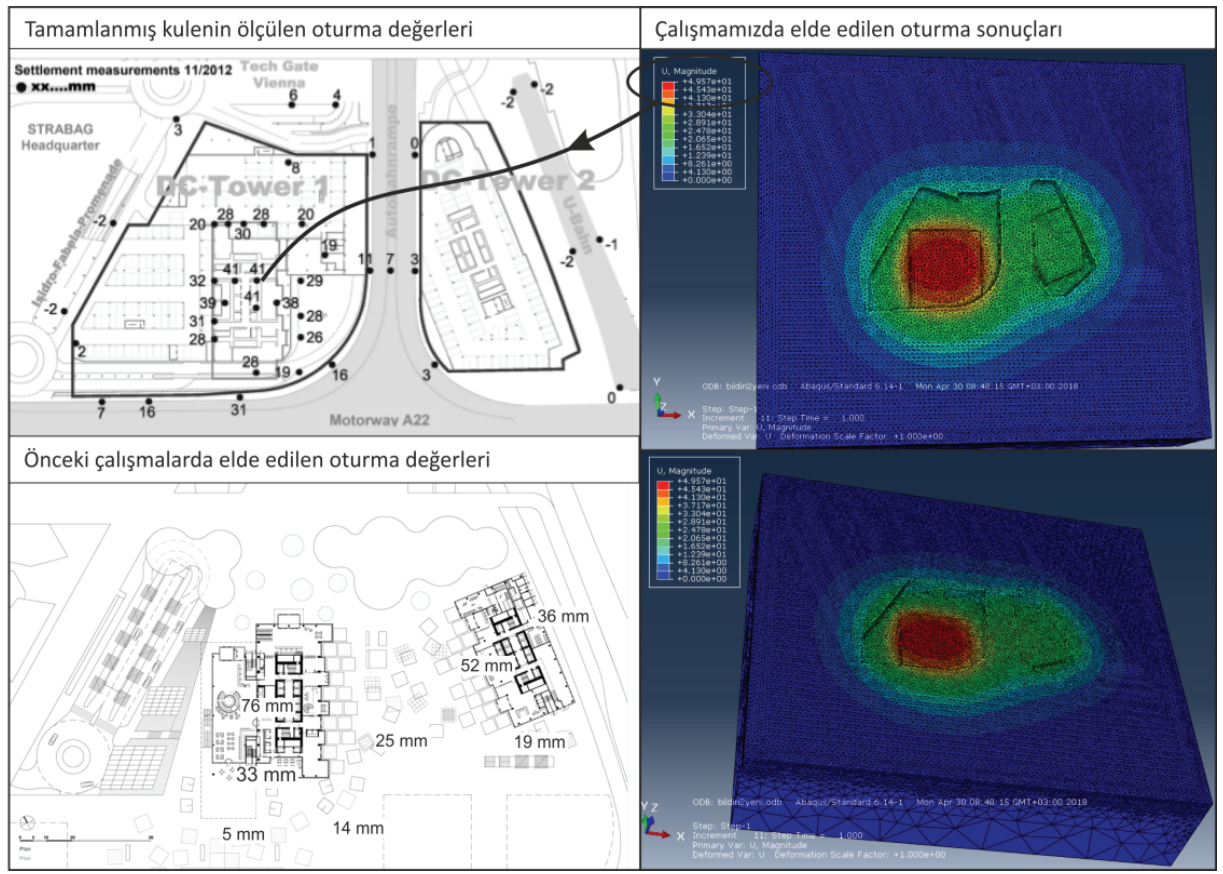

Şekil 8 - Analizler sonucunda elde edilen oturmalar ve ölçüm sonuçlarlyla kıyaslama 
Analizler sonucu elde edilen bulgular, Adam ve Markiewicz [24] tarafindan yapılan analiz sonuçları, birinci kulenin yapımının ardından yerinde yapılan ölçüm sonuçları (Şekil 8) ve Tschuchnigg ve Schweiger [25] tarafindan yapılmış nümerik analiz bulguları ile kıyaslanmıştır (Şekil 8). Şekil 8'de görülebileceği gibi elde edilen maksimum oturma değeri birinci kulenin yapımının ardından yerinde yapılan ölçüm sonuçları ile uyumludur. Oturma ölçümleri inşaat tamamlandıktan 1 yıl sonra temel düzeyinde ölçülmüş olup referans alınan kaynaklarda ne tür bir ölçüm cihazı ile ölçümlerin yapıldığına dair bir bilgiye rastlanılmamıştır. Adam ve Markiewicz [24] tarafından raporlandığı üzere, birinci kulenin inşasının tamamlanmasının ardından yerinde yapılan ölçümler sonucunda $41 \mathrm{~mm}$ oturma oluştuğu belirtilmiştir. Ancak, oturma ölçümlerinin yapıldığı sırada kulenin henüz kullanılmaya başlanmadığı belirtilmiştir. Şekil 8'de ölçüm sonuçları ile bu çalışma kapsamında elde edilen sonuçların kıyaslanması görülmektedir. Bu çalışmada elde edilen maksimum oturma değerinin, Adam ve Markiewicz'in [24] ve Tschuchnigg ve Schweiger'in [25] elde ettiği değerlerden daha az olduğu ve yerinde yapılan ölçüm sonuçları ile uyumlu olduğu ve görülmüş̧ür. Ayrıca hesaplamalarda her ne kadar 3B SE analizinde tanımlanan parametrelerin ve etkilerin tümünü baret kazıklı radyeler için birebir yansıtmasa da Hamderi [33] tarafından önerilen grup kazıkların oturma formülünden yararlanılarak bu sistem için 51 mm oturma elde edilmiştir. Bu değerin de, bu çalışmada 3B SE analizi ile hesaplanan oturma değeri ile uyumlu olduğu görülmektedir. Diğer çalışmalardan farklı olarak bu çalışmada, Algin [28-30] tarafindan tanıtılan görüntü işleme tekniği kullanılarak modelleme yapılmış ve 3B SE oturma analizleri gerçekleştirilmiştir.

$710 \mathrm{kPa}$ basınç kademesinde oturma analizinden bir kesit Şekil 9(a)'da sunulmuştur. Zemin deformasyonunun baretten yatay yönde uzaklaşmayla hızlı bir şekilde azaldığ 1 ve 1.5-2 baret derinliği kadar bir mesafe içerisinde bu deformasyonun minimal bir düzeye düştüğü görülmektedir. Fellenius ve diğ., [20] tarafından bu deformasyon azalışının bir baret mesafesi içerisinde olduğu belirtilmiş olsa da, yapılan analizler bu değerin 1.5-2 baret derinliği kadar bir genişliği kapsadığını ve baret yüksekliğinin yarısı kadar bir genişlikte bu deformasyon değerinin yarı yarıya azaldığını göstermiş̧tir. Ayrıca, baret tabanında, baret genişliği kadar bir derinlik içerisinde taban oturmasının \%20 mertebesinde azaldığı görülmüştür. Yapılan oturma analizlerine temel teşkil etmesi açısından bir referans hat seçilmiş ve Şekil 9(b)'de gösterilmiştir. Bu hat üzerinde tüm basınç kademelerinde yapılan analizlerden (100-710 kPa arasında dört kademede) alınan oturma değerleri kullanılarak temel sisteminin oturma analizi yapılmıştır. Bu analizlerde kullanılan terimler Şekil 10’da özetlenmiştir.

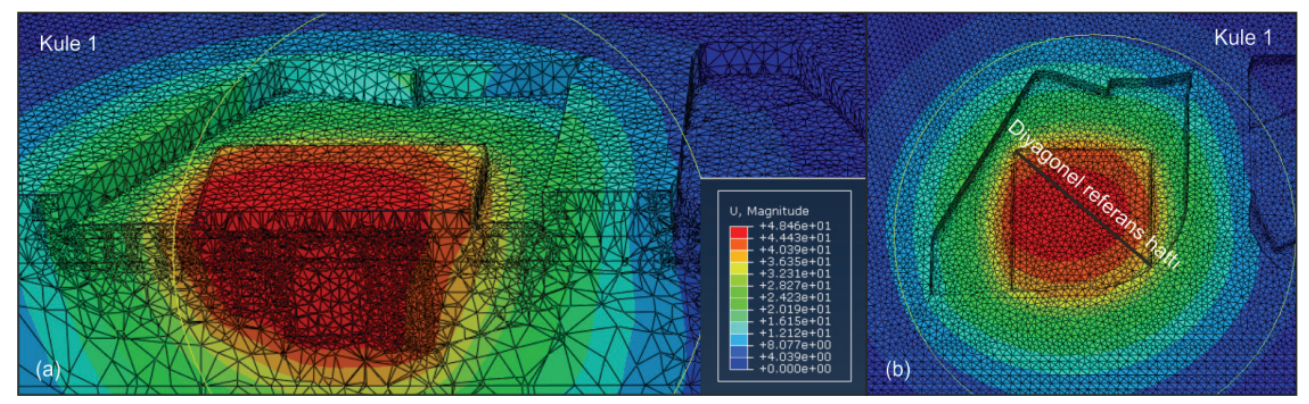

Şekil 9 - (a) 710 kPa basınç kademesindeki oturma analizinden bir kesit, (b) oturma analizlerinde referans alınan hattın konumu 


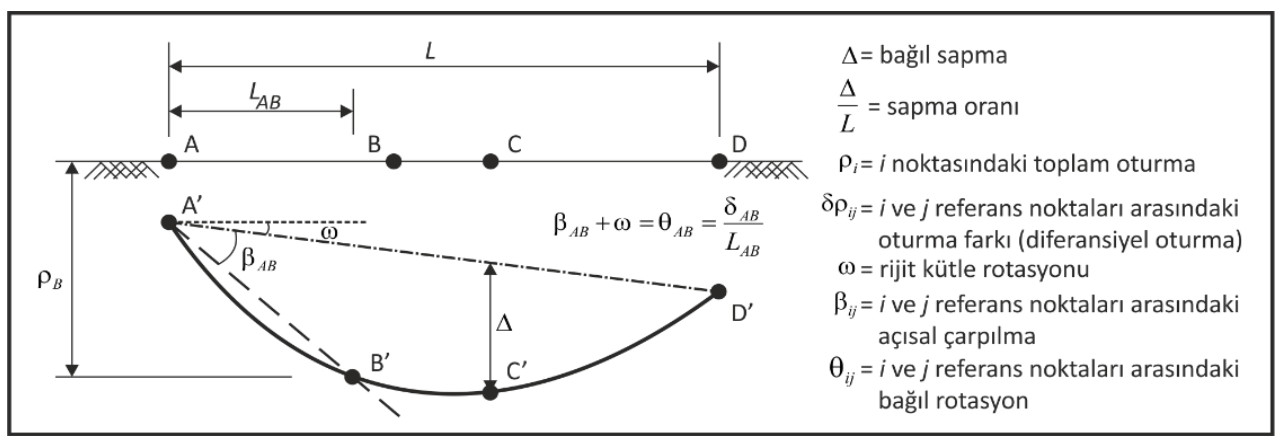

Şekil 10 - Oturma analizinde kullanılan terimler

100-710 $\mathrm{kPa}$ arasında dört aşamada uygulanan basınca ve Şekil 8(b)'de gösterilen referans hat üzerindeki mesafeye bağlı olarak oturma değerlerindeki değişim Şekil 11'de sunulmuştur. Yük kademelerindeki artışa bağlı olarak oturma değerlerinde artışın olduğunu gösteren bu grafik kullanılarak, Şekil 10'da tanımlanan oturma terimleri hesaplanmış olup, sonuçlar Şekil 12'de sunulmuştur. Şekil 12(a)'da bu uygulama basınç kademelerinde referans hattı üzerinde oluşan rijit kütle rotasyonu ve maksimum açısal çarpılma değerlerindeki değişim grafiklendirilmiştir. Şekil 12(b)'de ise uygulama basıncındaki değişime bağlı olarak maksimum bağıl rotasyon ve maksimum diferansiyel oturma arasındaki ilişki sunulmuştur. Tüm uygulama kademelerinde maksimum oturmanın yerinin referans diyagonel hat üzerinde değişmemesinden dolayı (bakınız Şekil 9b ve 11) maksimum bağıl rotasyon ile maksimum diferansiyel oturma Şekil 12(b)'de gösterildiği gibi aynı hat üzerinde oluşmaktadır.

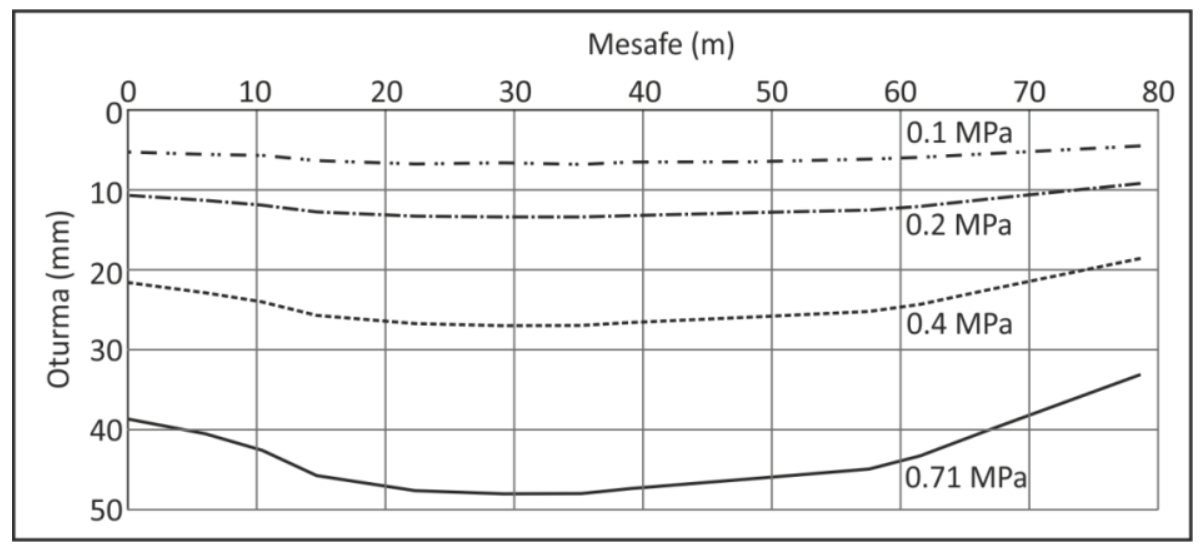

Şekil 11 - Diyagonal referans hat üzerindeki oturmaların uygulama basıncına bağlı değişimi

Şekil 11 ve 12 'de sunulan oturma değerleri literatürde verilen sınır değerleri ile karşılaştırılmıştır. Oturma limiti temel tabanının \%0.5'i olarak tanımlandığında [34] maksimum oturma değerleri aşılmamıştır. Diferansiyel oturma açısından ise bu limit değer 
Reul ve Randolph [35] tarafından temel genişliğinin binde biri olarak sınırlandırılmıştır. $\mathrm{Bu}$ durumda $56.3 \mathrm{~mm}$ diferansiyel oturma sınırı Şekil 12'de görüldüğü gibi aşılmamaktadır. Sarkma oturma profili temelinde açısal çarpılma sınır değeri ise Eurocode 1997'de hizmet edebilirlik düzeyinde 1/2000-1/300 olarak ifade edilmiş ve genel olarak 1/500 olarak alınabileceği belirtilmiştir. Bu durumda Şekil 12(a)'de görüldüğü üzere maksimum açısal çarpılma sınır değeri de aşılmamıştır.

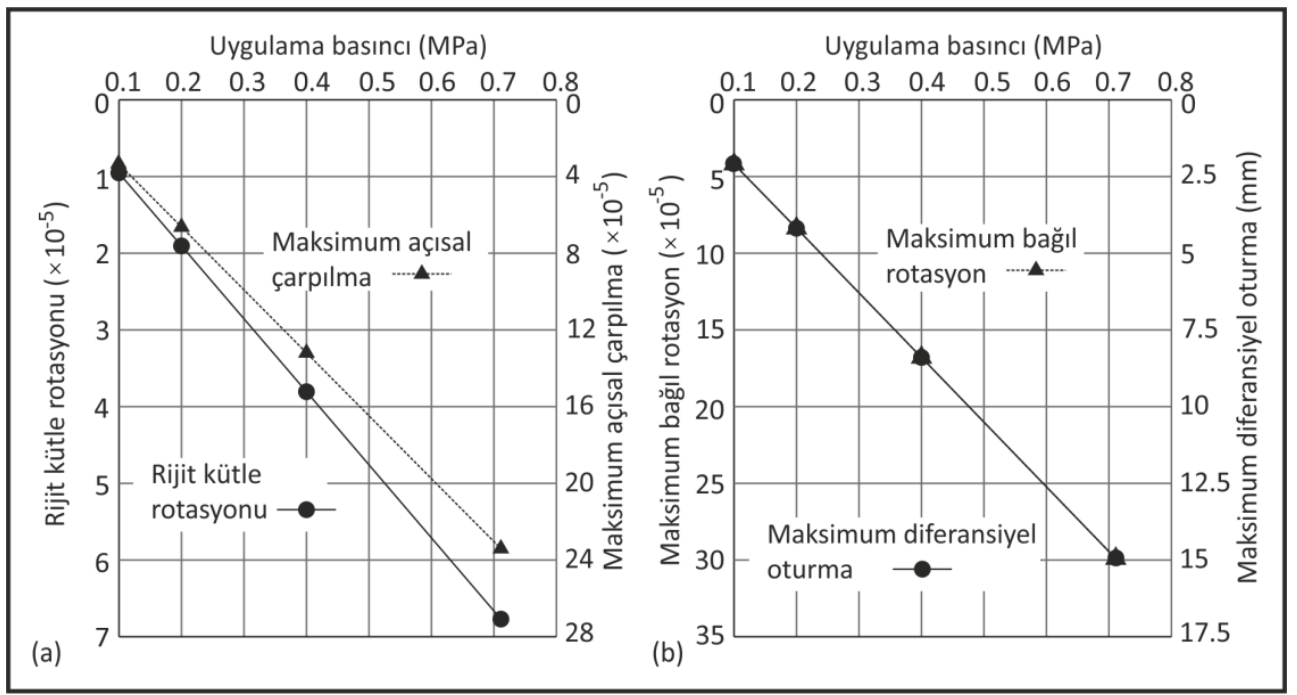

Şekil 12 - Uygulama basınç kademesindeki artışa bă̆lı olarak (a) rijit kütle rotasyonu ve maksimum açısal çarpılma dĕgerlerindeki değişim, (b) bă̆ll rotasyon ve diferansiyel oturma değerlerindeki değişim,

Yukarıda özetlenen oturma analizi, genelde ek olarak istenmedikçe kazık tasarımının günlük uygulamalarında yapılmamaktadır. Bunun yerine, statik yükleme testi tatmin edici bir güvenlik katsayısıyla çalışıldığını gösteriyorsa, oturmanın tatminkar düzeyde kalacağı kabulü yapılmaktadır. Bu her zaman doğru olmayıp, güvenli bir yöntem de değildir, zira bu yaklaşıma etki eden kazık gruplarının davranışı, komşu bina temel sistemi ve yüklemeleri, kazıkların konfigürasyonu ve baret kazık uyumlanmaları gibi faktörler, bu öngörüyü kapsamadığından ya aşırı güvenli tarafta kalıp ekonomik tasarımdan uzaklaşılmakta ya da güvensiz tasarım sonuçları doğabilmektedir. Bu belirsizliği ortadan kaldırıp, ekonomik ve güvenli bir şekilde baret kazıklı temel tasarımına olanak sağlayabilmek amacıyla, temel sisteminin bir bütün olarak yukarıda bahsedilen etkiler gözetilerek oturma analizinin yapılması ile bu yayında bu karmaşık temel sisteminin üç boyutlu olarak sonlu elemanlar metoduyla nasıl analiz edilebileceği açıklanmıştır.

$\mathrm{Bu}$ analizlerde baret kazıkların inşa aşamalarındaki etkiler dikkate alınmamış olup, analizler tamamen inşa sonrası durumu kapsayacak şekilde yapılmıştır. İnşa aşamasında kazıkların varsa birbirlerine olan etkisi, zeminde oluşabilecek değişim ve kemerlenme etkisi gibi etkiler dikkate alınmamıştır. Yan yüzey sürtünme direncine etki eden inşa süresi, kenar temizliği ve kullanılan kazı sistemi gibi etkiler de analizde göz önüne alınmamıştır. 


\section{SONUÇLAR}

Bu çalışma, farklı uzunluklardaki baret ve CFA grup kazıkları, diyafram duvar sistemi ve radye temel sistemleri ile birlikte komşu temel sistemlerini de dikkate alan karmaşık bir temel uygulamasının, görüntü işleme tekniğiyle üç boyutlu olarak modellenebileceğini ve sonlu elemanlar metodu kullanılarak analiz edilebileceğini göstermiştir. Yapılan analizler gerçek ölçüm sonuçlarına yakın değerler sağlamış olup, $30 \mathrm{~m}$ uzunluğundaki baret temellerin uzunluklarında bir miktar azaltmaya gidilebileceği sonucu ise maksimum oturmanın radye merkezi dışına ötelenerek üniform senaryoda eksantrisite oluşması temelinde ifade edilebilir. Ayrıca, oturmanın baretten yatay yönde uzaklaştıkça hızlı bir şekilde azaldığı ve 1.5-2 baret derinliği kadar bir mesafe içerisinde bu oturmanın minimal bir düzeye düştüğü görülmüştür. Baret yüksekliğinin yarısı kadar bir genişlikte bu oturma değerinin yarı yarıya azaldığı belirlenmiştir. Baret tabanında, baret genişliği kadar bir derinlik içerisinde taban oturmasının $\% 20$ mertebesinde azaldığı görülmüştür.

\section{Semboller}

$\beta_{i j} \quad: i$ ve $j$ referans noktaları arasındaki açısal çarpılma

$\gamma_{n} \quad$ : Doğal birim hacim ağırlık

$c^{\prime} \quad$ Kohezyon

$\Delta \quad:$ Bağıl sapma

$\frac{\Delta}{L} \quad$ : Sapma oranı

E : Elastisite modülü

$v \quad$ : Poison oranı

$\phi^{\prime} \quad$ : İçsel sürtünme açısı

$\delta \rho_{i j} \quad: i$ ve $j$ referans noktaları arasındaki oturma farkı (diferansiyel oturma)

$\omega \quad$ : Rijit kütle rotasyonu

$\theta i_{j} \quad: i$ ve $j$ referans noktaları arasındaki bağıl rotasyon

$\rho_{i} \quad: i$ noktasindaki toplam oturma

\section{Kaynaklar}

[1] Tamaro, G., Perimeter Wall for New World Center, J. Constr. Eng. Manage., 107(2), 193-207, 1981.

[2] Ramaswamy, S. D., Pertusier, E. M., Construction of Barrettes for High-Rise Foundations, J. Constr. Eng. Manage., 112(4), 455-462, 1986. 
[3] Pratt, M., Sims, M. J., The Application of New Techniques to Solve Deep Basement and Foundation Problems, Int. Conf. on Deep Foundation Practice, Singapore, 1990.

[4] Ann, T. S., Fellenius, B. H., Failure of a Barrette As Revealed in an O-cell Test, GeoCongress ASCE, Oakland, California, USA, 307-321, 2012.

[5] Thasnanipan, N., Maung, A. W., Baskaran, G., Diaphragm Wall and Barrette Construction for Thiam Ruam Mit Station Box, MTR Chaloem Ratchamongkhon Line, Bangkok, Int. Conf. on Geotechnical and Geologic Engineering, GeoEng 2000, Melbourne, Australia, 2000.

[6] Kienberger, H., Diaphragm Walls as Load Bearing Foundations, Diaphragm walls and anchorages, Institution of Civil Engineers, London, 19-21, 1975.

[7] Baker, C. N., Azam, I., Joseph, L. S., Settlement Analysis for 450 Meter Tall KLCC Towers, In Vertical and Horizontal Deformations of Foundations and Embankments, ASCE, 1650-1671, 1994.

[8] Martak, L., Mayerhofer, A.F., Tschuchnigg, F., Vorwagner, A., Bahnhof Wien Mitte Ein zentrales Infrastrukturprojekt im Herzen Wiens, Proc. 23th Christian Veder Kolloquium, Graz, 2007.

[9] Ng, C. W. W., Lei G. H., Performance of Long Rectangular Barrettes in Granitic Saprolites, Journal of Geotechnical and Geoenvironmental Engineering, ASCE, 129(8), 685-696, 2003.

[10] Geotechnical Engineering Office (GEO), Pile Design and Construction, GEO Publication No. 1/96, Civil Engineering Dept., Hong Kong Government, Hong Kong, 1996.

[11] Powrie, W., E. S. F. Li., Finite Element Analyses of an In Situ Wall Propped at Formation Level, Geotechnique, 41(4), 499-514, 1991.

[12] Gunn M. J., Satkunananthan, A., Clayton, C. R. I., Finite Element Modelling of Installation Effects, Retaining Structures, 46-55, 1993.

[13] Moran, J., Laimbeer, A., Behaviour During Construction of a Cantilever Diaphragm Wall in Stiff Clay at Limehouse Link, TRL Project Report 73, Transport Research Laboratory of the Department of Transport, Crowthorne, Berkshire, UK, 1994.

[14] Ng, C. W. W., An Evaluation of Soil-Structure Interaction Associated with a MultiPropped Excavation, PhD thesis, University of Bristol, U.K., 1992.

[15] Lings, M. L., Ng, C. W. W., Nash, D. F. T., The Lateral Pressure of Wet Concrete Diaphragm Wall Panels Cast Under Bentonite, Proc. Instn. Civ. Engrs, Geotech. Eng., 107(3), 163-172, 1994.

[16] Ng, C. W. W., Yan, R. W. M., Stress Tranfer and Deformation Mechanisms Around A Diaphragm Wall Panel, J. Geotech. And Geoenviron. Engng., ASCE, 124(7), 638-648, 1998.

[17] Ng, C. W. W., Yan R. W. M., Three-Dimensional Modelling of a Diaphram Wall Construction Sequance, Geotechnique, 49(6), 825-834, 1999. 
[18] Ng, C. W. W., Lings, M. L., Simpson B., Nash, D. F. T., An Approximate Analysis of the Three-Dimentional Effects of Diaphram Wall Installation, Geotechnique, 45(3), 497-507, 1995.

[19] Gourvenec, S. M., Powrie, W.,Three-Dimentional Finite Element Analysis of Diaphragm Wall Installation, Geotechnique, 49(6), 801-823, 1999.

[20] Fellenius, B. H., Altaee, A., Kulesza, R., Hayes, J., O-Cell Testing and FE Analysis of 28-m-Deep Barrette in Manila, Journal of Geotechnical and Geoenvironmental Engineering, ASCE, 125(7), 566-575, 1999.

[21] Lei, G., Behaviour of Excavated Rectangular Piles (Barrettes) in Granitic Saprolites, PhD Thesis, Dept. of Civil Eng. Hong Kong University of Science and Technology, Clear Water Bay, Kowloon, Hong Kong, 2001.

[22] Zhang, L. M., Behavior of Laterally Loaded Large-Section Barrettes, Journal of Geotechnical and Geoenvironmental Engineering, ASCE, 129(7), 639-648, 2003.

[23] Seo, H., Basu, D., Prezzi, M., Salgado, R., Load-Settlement Response of Rectangular and Circular Piles in Multilayered Soil, Journal of Geotechnical and Geoenvironmental Engineering, ASCE, 135(3), 420-430, 2009.

[24] Adam, D., Markiewicz, R., Donau City Tower 1 - Deep Foundation, Excavation and Dewaterings Cheme for the $220 \mathrm{M}$ Tall High-Rise Building in Vienna,Vplyv vody na geotechnic konštrukcie, Bratislava, 25(12), 2013.

[25] Tschuchnigg, F., Schweiger, H. F., Comparison of Deep Foundation Systems using 3D Finite Element Analysis Employing Different Modeling Techniques, Geotechnical Engineering Journal of the SEAGS \& AGSSEA, 44(3), 40-46, 2013.

[26] Tschuchnigg, F., Schweiger, H. F., Study of a Complex Deep Foundation System Using 3D Finite Element Analysis, Numerical Methods in Geotechnical Engineering (NUMGE 2010), London, 2010.

[27] Tschuchnigg, F., Schweiger, H. F., Comparison of Deep Foundation Systems Using 3D Finite Element Analysis, Proc. of IACMAG, Melbourne, Australia, 2011.

[28] Algin, H. M., Optimised Design of Jet-Grouted Raft Using Response Surface Method, Computers and Geotechnics, 74, 56-73, 2016.

[29] Algin, H. M., Optimised Design of Jet-Grouted Rafts Subjected to Nonuniform Vertical Loading, Korean Society of Civil Engineers (KSCE), 22(2), 494-508, 2017.

[30] Algin, H. M., Gumus, V., 3D FE Analysis on Settlement of Footing Supported with Rammed Aggregate Pier Group, International Journal of Geomechanics, American Society of Civil Engineers (ASCE), 18(8), 1-18, 2018.

[31] Matlab (2017). Matlab, version R2017a, MathWorks.

[32] Abaqus (2012). Abaqus, version 6.12, Dassault Systèmes, USA.

[33] Hamderi, M., Comprehensive Group Pile Settlement Formula Based on 3D Finite Element Analyses, Soils and Foundations , 58(1), 1-15, 2018. 
[34] BS-EN-1994-1. Eurocode 7. ,Geotechnical Design, Brussels, Belgium: European Committee for Standardization, 2004.

[35] Reul, O., Randolph, MF., Design Strategies for Piled Rafts Subjected to Nonuniform Vertical Loading, Journal of Geotechnical and Geoenvironmental Engineering, 130(1), $1-13,2004$. 